P-ISSN:

E-ISSN:

Email: ristansi@asia.ac.id

https://jurnal.stie.asia.ac.id/index.php/ristansi

\title{
TRADISI TOMPANGAN DALAM PERSPEKTIF AKUNTANSI
}

\author{
Dian Altika Sari \\ Universitas Wiraraja Madura \\ Alamat surel : dianaltika@gmail.com \\ DOI: doi.org// $\mathrm{xxxxx}$
}

Informasi Artikel

\begin{tabular}{ll}
\hline Tanggal Masuk & November \\
& $22^{\text {nd }}, 2020$ \\
Tanggal Revisi & December \\
& $2^{\text {nd }}, 2020$ \\
Tanggal diterima & December \\
& $17^{\text {th }}, 2020$
\end{tabular}

Keywods:

Tompangan

tradition,

Debt,

Treatment of

assets

\begin{abstract}
:
This study discusses the tompangan tradition from an accounting perspective in a group of young shoots. The purpose of this research is to reveal the meaning of tompangan tradition from an accounting perspective and to describe the treatment of tompangan assets in terms of those who give and receive donations. The object of this research is the group of young shoots in the village of Paberasan, Sumenep Regency. In this study, researchers used a qualitative research type with a case study approach, where researchers obtained data through observation, interviews and documentation. The data analysis technique used in this research is data reduction, data presentation and conclusion drawing and verification. The data validity test used in this study is through the source triangulation technique. The results of this study indicate that in the implementation of the tompangan tradition, there is a meaning that is recognized as a payable account, this is due to the obligation to return the donations received and the right to receive back donations previously given, besides that there is also a greater return of the donations made previously accepted which creates binding stress. Meanwhile, the treatment of assets towards donations in the tompangan tradition has been carried out quite well, although in the treatment of assets towards donations it is carried out simply with their understanding.
\end{abstract}

\section{Kata Kunci:}

Tradisi tompangan,

Utang,

Perlakuan Aset.

\section{Abstrak:}

Penelitian ini membahas tentang tradisi tompangan dalam perspektif akuntansi di grup tunas muda. Adapun tujuan dalam penelitian ini yaitu untuk mengungkap makna tradisi tompangan dalam perspektif akuntansi serta untuk menguraikan perlakuan terhadap aset tompangan ditinjau dari yang memberi dan menerima sumbangan. Objek dalam penelitian ini yaitu di grup tunas muda yang berada di Desa Paberasan Kabupaten Sumenep. Dalam penelitian ini, peneliti menggunakan jenis 
penelitian kualitatif dengan pendekatan studi kasus, dimana peneliti memperoleh data melalui observasi, wawancara dan dokumentasi. Teknik analisis data yang digunakan dalam penelitian ini yaitu dengan menggunakan reduksi data, penyajian data serta penarikan kesimpulan dan verifikasi. Adapun uji keabsahan data yang digunakan dalam penelitian ini yaitu melalui teknik triangulasi sumber. Hasil penelitian ini menunjukkan bahwa dalam pelaksanaan tradisi tompangan terdapat adanya makna yang diakui sebagai hutang piutang, hal ini dikarenakan adanya kewajiban untuk mengembalikan sumbangan yang diterima serta hak untuk menerima kembali sumbangan yang diberikan sebelumnya, selain itu juga terdapat adanya pengembalian yang lebih besar dari sumbangan yang diterima sebelumnya yang menyebabkan adanya tekanan yang bersifat mengikat. Sedangkan untuk perlakuan aset terhadap sumbangan yang ada dalam tradisi tompangan sudah dilakukan dengan cukup baik, walaupun dalam perlakuan aset terhadap sumbangan tersebut dilakukan secara sederhana dengan pemahaman yang mereka miliki.

\section{PENDAHULUAN}

Masyarakat Madura memiliki berbagai ragam budaya dengan ciri khas yang unik dan sampai saat ini masih tetap mendarah daging dalam kehidupan setiap individu. Selain itu masyarakat Madura juga memiliki berbagai macam tradisi yang diyakini serta menjadi kebiasaan secara turun temurun. Salah satu tradisi yang sampai saat ini masih tetap dipertahankan oleh masyarakat Madura yaitu tradisi sumbang menyumbang yang dikenal dengan sebutan tompangan.

Tradisi tompangan sering terjadi dalam acara pernikahan di Madura. Dalam pelaksanaan tradisi tompangan terdapat adanya sumbangan yang diberikan oleh keluarga, masyarakat maupun tamu undangan. Sumbangan tersebut dapat berupa uang, barang seperti beras, telur, gula dan lain sebagainya. Selain itu dalam pelaksanaan tradisi tompangan juga terdapat petugas yang melakukan pencatatan terkait dengan pertanggungjawaban atas besarnya sumbangan yang diberikan. Tujuan adanya pencatatan tersebut yaitu untuk mengetahui bahwa sumbangan yang diberikan termasuk dalam kelompok calon atau balin, yang dimaksud kelompok calon yaitu sumbangan yang diberikan merupakan pemberian yang pertama kali diberikan dan harus dikembalikan pada masa yang akan datang, sedangkan kelompok balin yaitu sumbangan yang diberikan merupakan pengembalian terkait dengan sumbangan yang diterima sebelumnya.

Beberapa studi berusaha membahas tentang fenomena yang terjadi, hal ini sejalan dengan penelitian yang diteliti oleh Saputri \& Ashari (2019), yang menyatakan bahwa dalam tradisi buwuh terdapat sumbangan yang diakui sebagai hibah karena dalam praktinya murni adanya balasan atau imbalan terhadap bantuan yang diberikan kepada 
pemilik hajat. Sedangkan pihak lain menyatakan bahwa dalam tradisi buwuh terdapat adanya bantuan yang diakui sebagai utang piutang karena terdapat kewajiban yang harus dikembalikan, hal ini disebabkan karena pihak yang melakukan hajatan merasa tidak enak kepada pihak yang memberikan sumbangan sehingga timbul keinginan untuk membalas sumbangan tersebut.

Melihat fenomena yang diuraikan oleh Saputri \& Ashari (2019), maka dalam penelitian ini peneliti akan mengungkap tradisi tompangan yang terjadi dalam acara pernikahan masyarakat Paberasan, dimana dalam tradisi tompangan yang terjadi di Desa Paberasan Kabupaten Sumenep terdapat adanya sumbangan yang menjadi kewajiban untuk dikembalikan atau dilunasi pada masa yang akan datang dengan nominal yang sama atau lebih besar dari nominal sebelumnya serta terdapat adanya hak untuk menerima kembali sumbangan yang diberikan sebelumnya, selain itu penelitian ini juga akan mengungkap bahwa sumbangan yang diberikan oleh keluarga maupun tamu undangan nantinya akan menjadi aset bagi pihak yang melakukan acara pernikahan.

Tradisi tompangan yang terjadi di Desa Paberasan Kabupaten Sumenep merupakan tradisi yang unik dan menarik sebab masyarakat setempat memiliki kebiasaan yang melibatkan banyak orang dalam mempertanggungjawabkan sumbangan yang ada di dalam pesta pernikahan serta untuk mengkoordinir tradisi tompangan masyarakat Desa Paberasan membentuk suatu grup yang diberi nama "grup tunas muda" dimana dalam grup tersebut terdapat masyarakat yang menjadi ketua serta anggota yang ikut berpartisipasi dalam acara pernikahan. selain itu, grup tunas muda juga memiliki keunikan, karena undangan yang ada di dalam grup tunas muda tersebut berbeda dengan undangan pernikahan pada umumnya. Dimana undangan yang ada di dalam grup tunas muda tersebut menggunakan barang berupa rokok, selain itu juga terdapat adanya kwitansi dan daftar hadir yang dapat memperkuat pertanggungjawaban terkait dengan sumbangan yang ada dalam acara pernikahan.

Tradisi tompangan dalam acara pernikahan tidak terlepas dari adanya praktik akuntansi, karena terdapat hubungan timbal balik yang harus dipertanggungjawabkan terkait dengan sumbangan yang diterima maupun yang diberikan sebelumnya, sehingga tanpa disadari dalam tradisi tompangan terdapat adanya sumbangan yang diakui sebagai utang maupun piutang, hal ini disebabkan karena adanya kewajiban yang harus dikembalikan oleh tuan rumah serta adanya sumbangan yang akan di terima kembali oleh tamu undangan pada masa yang akan datang. Selain itu dalam pelaksanaan tradisi tompangan sumbangan yang diterima oleh tuan rumah maupun sumbangan yang diberikan oleh tamu undangan nantinya akan diakui sebagai aset mereka, hal ini dikarenakan dalam pelaksanaan tradisi tompangan tuan rumah dapat mengakui sumbangan sebagai aset pada saat sumbangan tersebut sudah diterima, sedangkan tamu undangan dapat mengakui sumbangan sebagai aset pada saat sumbangan tersebut sudah diberikan kepada pihak yang melakukan acara pernikahan.

Dalam tradisi tompangan juga terdapat bahan bukti berupa kwitansi yang digunakan sebagai bentuk pertanggungjawaban terkait dengan sumbang-menyumbang dalam acara pernikahan. Oleh karena itu tradisi tompangan tersebut tidak terlepas dari adanya pencatatan yang bertujuan untuk mengetahui transaksi antar kedua belah pihak, walaupun tidak secara keseluruhan transaksi tersebut mangandung praktik akuntansi yang berlaku. 
Hubungan timbal balik dalam mempertanggungjawabkan sumbangan yang terjadi di dalam tradisi tompangan mengakibatkan seseorang memiliki kewajiban untuk mengambalikan sumbangan pada masa yang akan datang dengan nominal yang sama maupun dengan nominal yang lebih besar. Selain itu seseorang juga memiliki hak untuk menerima kembali sumbangan yang diberikan sebelumnya baik dalam jangka waktu dekat maupun jangka waktu yang masih lama.

Menelaah fenomena yang telah diuraikan dalam latar belakang, maka peneliti tergugah untuk melakukan penelitian di grup tunas muda dengan judul "Tradisi Tompangan Dalam Perspektif Akuntansi".

Berdasarkan uraian diatas, tujuan dari penelitian ini diharapkan dapat mengungkap makna tradisi tompangan dalam perspektif akuntansi di grup tunas muda serta dapat menguraikan perlakuan terhadap aset "tompangan" ditinjau dari yang memberi dan menerima sumbangan dalam tradisi tompangan.

\section{TINJAUAN PUSTAKA}

\section{Teori Resiprositas}

Resiprositas dalam analisis teori pertukaran merupakan bentuk pertukaran yang memiliki hubungan timbal balik antara individu maupun antar kelompok (Pribadhi, 2011).

Menurut Damsar \& Indrayani (2016:105), terdapat dua jenis resiprositas yaitu resiprositas sebanding dan resiprositas umum. Resiprositas sebanding merupakan kewajiban untuk membalas atau membayar kepada orang atau kelompok lain atas apa yang mereka berikan kepada kita. Sedangkan resiprositas umum adalah kewajiban memberi atau membantu orang tanpa mengharapkan pengembalian atau balasan yang setara.

\section{Tradisi Tompangan}

Tradisi merupakan suatu gambaran sikap dan perilaku manusia yang telah berproses dalam waktu lama dan dilakukan secara turun- temurun dimulai dari nenek moyang (Margahana \& Triyanto, 2019).

Salah satu tradisi yang ada di dalam acara pernikahan orang Madura adalah tradisi tompangan, tradisi tompangan dalam acara pernikahan sama halnya dengan tradisi sumbang-menyumbang yang dalam bahasa jawa biasa disebut tradisi buwuh atau buwuhan. Menurut Geertz (2014:84), buwuh adalah jenis sumbangan uang yang khas dari para tamu yang datang dalam hajatan pernikahan kepada tuan rumah karena sudah menerima hidangan dan pelayanan dari tuan rumah.

\section{Akuntansi}

Akuntansi adalah suatu seni (dikatakan seni karena perlu kerapian, ketelitian, kebersihan) pencatatan, penggolongan, peringkasan dan pelaporan dengan cara yang baik dalam unit moneter atas transaksi-transaksi keuangan dan kejadian - kejadian lain sehubungan dengan keuangan perusahaan dan menafsirkan hasil-hasil pencatatan tersebut (Hantono \& Rahmi, 2018:2).

\section{Makna Utang Dalam Akuntansi}

Menurut Hantono \& Rahmi (2018:16), utang adalah semua kewajiban perusahaan yang harus dilunasi yang timbul sebagai akibat pembelian barang secara kredit ataupun penerimaan pinjamanan. 


\section{Makna Piutang Dalam Akuntnasi}

Piutang merupakan aset keuangan yang mencerminkan hak kontraktual untuk menerima sejumlah kas di masa depan atau hak tagih terhadap pihak lain atas kas, barang atau jasa (Sasongko et al, 2017:204).

\section{Makna Aset Dalam Akuntansi}

Aset merupakan sumber-sumber ekonomik yang dimiliki perusahaan dan diharapkan dapat memberikan manfaat di masa yang akan datang (Sochib, 2018:44). Perlakuan aset meliputi:

1. Pengakuan Aset

Menurut IAI, aset diakui dalam neraca jika benar kemungkinan bahwa manfaat ekonomiknya di masa depan diperoleh perusahaan dan aset tersebut mempunyai nilai atau biaya yang dapat diukur dengan andal.

2. Pengukuran Aset

Menurut IAI, dasar pengukuran yang berbeda digunakan dalam derajat dan kombinasi yang berbeda dalam laporan keuangam. Dasar pengukuran aset adalah sebagai berikut: (a) biaya historis, aset dicatat sebesar pengeluaran kas (atau setara kas) yang dibayar sebesar nilai wajar dari imbalan yang diberikan untuk memperoleh aset tersebut pada saat perolehan. (b) biaya kini, aset dinilai dalam jumlah kas (atau setara kas) yang seharusnya dibayar bila aset yang sama atau setara kas diperoleh sekarang. (c) milai realisasi/penyelesaian, aset dinyatakan dalam jumlah kas (atau setara kas) yang dapat diperoleh sekarang dengan menjual aset dalam pelepasan normal. (d) nilai sekarang, aset dinyatakan sebesar arus kas masuk bersih di masa depan yang didiskontokan ke nilai sekarang dari pos yang diharapkan dapat memberikan hasil dalam pelaksanaan usaha normal.

3. Pencatatan Aset

Menurut PSAK 55, pembelian atau penjualan aset keuangan diakui dan dihentikan pengakuannya menggunakan salah satu di antara akuntansi tanggal perdagangan atau akuntansi tanggal penyelesaian.

4. Pelaporan Aset

Menurut PSAK 1, dalam pelaporan aset yang disajikan di dalam laporan posisi keuangan minimal mencakup penyajian jumlah pos-pos sebagai berikut: aset tetap, property investasi, aset tak berwujud, aset keuangan, investasi yang dicatat dengan menggunakan metode ekuitas, persediaan, piutang dagang dan piutang lain, kas dan setara kas dan total aset yang diklasifikasikan sebagai aset yang dimiliki untuk dijual dan aset yang termasuk dalam kelompok lepasan yang diklasifikasikan sebagai dimiliki untuk dijual.

\section{METODE PENELITIAN}

Jenis penelitian ini merupakan metode penelitian kualitatif. Peneliti tertarik untuk menggunakan metode penelitian kualitatif karena peneliti berusaha untuk menggambarkan bagaimana makna tradisi tompangan dalam perspektif akuntansi serta perlakuan terhadap aset tompangan yang ada di Grup Tunas Muda Paberasan. Dalam penelitian ini, peneliti menggunakan satu pendekatan sebagai alat untuk menganalisis sebuah riset yaitu pendekatan studi kasus, karena dengan pendekatan ini peneliti akan 
mengungkap makna atas pengalaman informan yang berhubungan dengan tradisi tompangan dalam perspektif akuntansi yang terjadi di dalam acara pernikahan.

Jenis data yang digunakan dalam penelitian ini yaitu data subjek. Dimana data subjek dalam penelitian ini berupa opini, sikap dan pengalaman dari informan yang menjadi objek dari penelitian. Teknik pengambilan sampel dalam penelitian ini yaitu menggunakan snowball sampling, dimana dalam teknik ini peneliti pertama kali menentukan satu sampel, kemudian untuk menentukan sampel berikutnya diperoleh berdasarkan saran dari sampel pertama. Sumber data yang digunakan dalam penelitian ini yaitu data primer. Dimana data primer dalam penelitian ini berbentuk kualitatif yang diperoleh dari hasil wawancara dan pengamatan secara langsung dengan memberikan beberapa pertanyaan kepada informan kunci maupun informan pendukung terkait dengan tradisi tompangan di grup tunas muda.

Untuk memperoleh informasi yang relevan, maka peneliti terlebih dahulu mencari dan mengumpulkan data. Menurut Sugiyono (2015:309), terdapat beberapa teknik yang dapat digunakan untuk memperoleh data, teknik pengumpulan data dalam penelitian ini yaitu melalui observasi, wawancara dan dokumentasi. Tahapan selanjutnya yang dilakukan oleh peneliti untuk menganalisis data yaitu melalui Reduksi data, Penyajian data, dan Penarikan kesimpulan dan verifikasi.

Dalam menetapkan keabsahan data diperlukan adanya teknik pemeriksaan, data yang dikumpulkan diklarifikasi sesuai dengan tujuan peneliti untuk dilakukan pengecekan kebenaran melalui triangulasi. Dalam penelitian ini peneliti menggunakan triangulasi sumber yang diartikan sebagai teknik pengumpulan data yang bersifat menggabungkan dari berbagai teknik pengumpulan data dan sumber data yang ada serta untuk menguji kredibilitas data dalam memastikan data yang diperoleh sesuai dengan keadaan yang terjadi (Sugiyono, 2015:330). Untuk menguji keterandalan data yang diperoleh maka peneliti akan membandingkan data dari hasil observasi dengan hasil wawancara serta hasil dokumentasi yang diperoleh melalui tiga informan yakni ketua grup tunas muda, budayawan dan masyarakat yang terlibat dalam tradisi tompangan.

\section{HASIL PENELITIAN DAN PEMBAHASAN \\ Makna Tradisi Tompangan Dalam Perspektif Akuntansi di Grup Tunas Muda Paberasan}

Tradisi tompangan merupakan tradisi turun temurun yang pada umumnya sudah ada dalam acara pernikahan di Madura, seperti halnya tradisi tompangan yang terjadi pada grup tunas muda di Desa Paberasan Kabupaten Sumenep. Dalam pelaksanaan tradisi tompangan terdapat beberapa tahapan atau kegiatan yang sering dilakukan pada saat acara pernikahan berlangsung. Salah satu kegiatan yang terjadi pada saat pelaksanaan tradisi tompangan di grup tunas muda yaitu masyarakat pada umumnya akan memberikan sumbangan yang dimiliki baik dalam bentuk uang maupun barang seperti kebutuhan dapur dan perlengkapan untuk acara pernikahan. Bentuk sumbangan tersebut nantinya akan dipertanggungjawabkan oleh kedua belah pihak yang ikut berpartisipasi dalam pelaksanaan tradisi tompangan.

Selain bentuk sumbangan hal yang lain yang perlu diperhatikan dalam pelaksanaan tradisi tompangan yaitu cara nyumbang. Cara nyumbangyang terjadi dalam pelaksanaan tradisi tompangan ditentukan oleh bentuk sumbangan yang akan diberikan baik dari 
pihak kerabat maupun tamu undangan pada saat resepsi berlangsung. Hal ini menunjukam bahwa bentuk sumbangan yang diberikan akan menjadi penentu cara nyumbang dalam tradisi tompangan pada saat acara pernikahan berlangsung. Sehingga dalam pelaksanaan tradisi tompangan bentuk sumbangan dan cara nyumbang tersebut dijadikan sebagai kebiasaan yang sering dilakukan di grup tunas muda pada saat pelaksanaan tradisi tompangan.

Masyarakat setempat memiliki kepercayaan bahwa terdapat makna yang terkandung dalam pelaksanaan tradisi tompangan yang terjadi dalam acara pernikahan. Berikut makna yang terkandung pada saat pelaksanaan tradisi tompangan yang terjadi dalam acara pernikahan di grup tunas muda:

Pertama, dalam pelaksanaan tradisi tompangan pihak yang menerima sumbangan memaknai bahwa dalam pelaksanaan tradisi tompangan terdapat praktik utang, hal ini dikarenakan adanya hubungan timbal balik yang menjadi kewajiban untuk dikembalikan terkait dengan sumbangan yang pernah diterima sebelumnya. Sehingga berapapun uang atau barang yang perna diterima sebelumnya harus diganti dengan jumlah yang sama bahkan lebih besar dari dari yang mereka terima di awal, jumlah uang yang disumbangkan tergantung dari hubungan jarak antara yang bersangkutan dengan tuan rumah yang melakukan acara pernikahan. Praktik utang yang terjadi dalam pelaksanaan tradisi tompangan sesuai dengan prinsip utang dimana menurut Hantono \& Rahmi (2018:16), menyatakan bahwa utang merupakan kewajiban yang harus dilunasi yang timbul sebagai akibat pembelian barang secara kredit ataupun penerimaan pinjamanan.

Kedua, dalam pelaksanaan tradisi tompangan di grup tunas muda diketahui bahwa pihak yang pernah memberikan sumbangan namun belum melakukan acara pernikahan memaknainya sebagai piutang, hal ini dikarenakan nantinya pada saat mereka melakukan acara pernikahan akan menerima kembali sumbangan yang pernah diberikan sebelumnya. Sebab dalam pelaksanaan tradisi tompangan terdapat hubungan timbal balik yang menyebabkan adanya hak untuk menerima kembali uang atau barang pada masa yang akan datang, bahkan pihak yang bersangkutan nantinya akan menerima kembali uang atau barang dengan jumlah yang lebih besar dari jumlah yang pernah diberikan sebelumnya. Praktik piutang yang terjadi dalam pelaksanaan tradisi tompangan sesuai dengan prinsip piutang, dimana piutang merupakan aset keuangan yang mencerminkan hak kontraktual untuk menerima sejumlah kas di masa depan atau hak tagih terhadap pihak lain atas kas, barang atau jasa (Sasongko et al. 2017:204).

Selain itu dalam pelaksanaan tradisi tompangan juga terdapat bentuk pertanggungjawaban terkait dengan sumbangan antar kedua belah pihak yaitu berupa adanya daftar hadir dan kwitansi.

\section{Perlakuan Terhadap Aset Tompangan Ditinjau Dari Yang Memberi Dan Menerima Sumbangan Dalam Tradisi Tompangan}

Perlakuan terhadap aset tompangan tersebut dapat dikatakan memiliki peran penting terhadap sumbangan yang ada dalam pelaksanaan tradisi tompangan, diantaranya sebagai berikut:

1. Pengakuan aset

Sumbangan yang ada dalam pelaksanaan tradisi tompangan dapat diakui sebagai aset apabila sumbangan tersebut memberikan manfaat ekonomik pada masa yang akan datang serta mempunyai nilai yang dapat diukur dengan andal. 
Pengakuan aset bagi pihak yang memberikan sumbangan tersebut diakui pada saat pertama kali mereka memberikan sumbangan kepada orang lain, dimana manfaat ekonomiknya akan diperoleh pada masa yang akan datang pada saat pengembalian terkait dengan sumbangan yang diberikan sebelumnya. Selain itu bagi pihak yang menerima sumbangan pengakuan aset dilakukan dengan cara mengakui sumbangan sebagai aset ketika sumbangan tersebut sudah diterima oleh tuan rumah dan manfaat ekonomiknya diperoleh pada saat hasil sumbangan tersebut dijual. Sedangkan bagi pihak atau anggota yang meninggal sumbangan tersebut nantinya diturunkan kepada anak cucunya sehingga dapat diakui sebagai aset ketika sumbangan tersebut dikembalikan dan diterima oleh anak cucunya nanti dan masa manfaatnya akan diterima pada masa yang akan datang pada saat anak cucunya tersebut melakukan acara pernikahan.

Selanjutnya berdasarkan pengakuan aset menurut IAI menyatakan bahwa aset diakui jika benar kemungkinan bahwa manfaat ekonomiknya di masa depan diperoleh perusahaan dan aset tersebut mempunyai nilai atau biaya yang dapat diukur dengan andal.

2. Pengukuran aset

Pelaksanaan tradisi tompangan di grup tunas muda baik dari pihak yang memberikan maupun yang menerima sumbangan melakukan pengukuran aset terhadap sumbangan tersebut menggunakan atau berdasarkan nilai sekarang, walaupun dalam pengukurannya masih dilakukan secara sederhana dengan pemahaman yang mereka miliki.

Pengukuran aset terhadap sumbangan dalam pelaksanaan tradisi tompangan di grup tunas muda dilakukan dengan pengukuran aset berdasarkan nilai sekarang. Hal ini dikarenakan dalam pelaksanaan tradisi tompangan pihak yang memberi maupun yang menerima sumbangan dalam praktiknya menyesuaikan dengan nilai harga yang terbaru, sebab dalam pelaksanaan tradisi tompangan pihak yang bersangkutan nantinya akan mengembalikan uang atau barang pada masa yang akan datang dengan jumlah yang lebih besar, hal ini dikarenakan mereka menyesuaikan dengan harga barang yang terbaru, selain itu mereka juga beranggapan bahwa nilai mata uang untuk setiap tahunnya berubah, sehingga mereka merasa tidak enak ketika mengembalikan uang dengan nominal yang sama dengan nominal uang yang diterima sebelumnya.

Selanjutnya berdasarkan pengukuran aset menurut IAI menyatakan bahwa dasar pengukuran berdasarkan nilai sekarang menyatakan bahwa aset dinyatakan sebesar arus kas masuk bersih di masa depan yang didiskontokan ke nilai sekarang dari pos yang diharapkan dapat memberikan hasil dalam pelaksanaan usaha normal.

3. Pencatatan aset

Pelaksanaan tradisi tompangan yang terjadi di grup tunas muda baik dari pihak yang memberi maupun yang menerima sumbangan terdapat adanya proses pencatatan terkait dengan sumbangan yang ada dalam tradisi tompangan.

Pencatatan yang dilakukan di grup tunas muda baik dari pihak yang memberi maupun yang menerima sumbangan menggunakan pencatatan secara sederhana dengan cara mencatat sumbangan dalam daftar hadir dan kwitansi pada saat acara pernikahan berlangsung. Karena mereka beranggapan bahwa dalam pelaksanaan 
tradisi tompangan pencatatan antar kedua belah pihak sangat penting agar pertanggungjawaban terkait dengan sumbangan tersebut dapat dipertanggungjawabkan dengan sebaik mungkin, sehingga mereka melakukan pencatatan dalam kwitansi dan daftar hadir sebagai salah satu cara untuk memastikan sumbangan antar kedua belah pihak yang terlibat dalam pelaksanaan tradisi tompangan dapat dipertanggungjawabkan dengan baik di kemudian hari.

Selanjutnya berdasarkan pencatatan aset menurut PSAK 55 menyatakan bahwa pembelian atau penjualan aset keuangan diakui dan dihentikan pengakuannya menggunakan salah satu di antara tanggal akuntansi tanggal perdagangan atau akuntansi tanggal penyelesaian.

4. Pelaporan aset

Pelaksanaan tradisi tompangan yang terjadi di grup tunas muda baik dari pihak yang memberi maupun yang menerima sumbangan terdapat adanya pelaporan terkait dengan sumbangan yang ada dalam tradisi tompangan, walaupun dalam pelaksanaanya masih dilakukan secara sederhana berdasarkan pemahaman yang mereka miliki.

Dalam pelaksanaan tradisi tompangan di grup tunas muda baik dari pihak yang menerima sumbangan maupun yang memberikan sumbangan, mereka melakukan pelaporan aset secara sederhana sesuai sistem dan pemahaman yang mereka miliki, tanpa mengikuti sistem akuntansi yang berlaku. Dimana sistem pelaporan yang mereka gunakan hanya berpacu pada daftar hadir dan kwitansi. Karena bagi mereka dengan adanya kwitansi dan daftar hadir dapat menjadi bukti yang kuat untuk pertanggungjawaban antar kedua belah pihak.

Selanjutnya berdasarkan pelaporan aset menurut PSAK 1 menyatakan bahwa pelaporan aset yang disajikan di dalam laporan posisi keuangan minimal mencakup penyajian jumlah pos-pos sebagai berikut: aset tetap, property investasi, aset tak berwujud, aset keuangan, investasi yang dicatat dengan menggunakan metode ekuitas, persediaan, piutang dagang dan piutang lain, kas dan setara kas dan total aset yang diklasifikasikan sebagai aset yang dimiliki untuk dijual dan aset yang termasuk dalam kelompok lepasan yang diklasifikasikan sebagai dimiliki untuk dijual.

Perlakuan aset tompangan yang terjadi di grup tunas muda ditinjau baik dari yang memberi maupun yang menerima sumbangan mulai dari proses pengakuan, pengukuran, pencatatan dan pelaporan dapat diketahui bahwa perlakuan aset terhadap sumbangan tersebut telah dilakukan dengan cukup baik, walaupun dalam perlakuan aset terhadap sumbangan tersebut dilakukan secara sederhana dengan pemahaman yang mereka miliki.

\section{KESIMPULAN}

Pertama, pelaksanaan tradisi tompangan dari pihak yang menerima sumbangan pada saat melakukan acara pernikahan memaknai tradisi tompangan tersebut sebagai utang, hal ini dikarenakan bagi pihak yang menerima sumbangan mempunyai kewajiban untuk mengembalikan terkait dengan sumbangan yang diterima sebelumnya. Sedangkan dari pihak yang memberikan sumbangan memaknai tradisi tompangan tersebut sebagai piutang, hal ini dikarenkan bagi pihak yang memberikan sumbangan mempunyai hak 
untuk menerima kembali bahkan menagih sumbangan yang pernah diberikan sebelumnya kepada pihak yang pernah melakukan acara pernikahan. Selain itu bentuk pertanggungjawabkan yang terjadi dalam pelaksanaan tradisi tompangan yaitu berupa daftar hadir dan kwitansi, sehingga dengan adanya daftar hadir dan kwitansi tersebut dapat memperkuat pertanggungjawabkan antar kedua belah pihak terkait dengan sumbangan yang ada dalam pelaksanaan tradisi tompangan.

Kedua, perlakuan terhadap aset tompangan yang ditinjau baik dari yang memberi dan menerima sumbangan yang terjadi di grup tunas muda sudah dilakukan dengan cukup baik, walaupun dalam perlakuan aset terhadap sumbangan tersebut dilakukan secara sederhana dengan pemahaman yang mereka miliki. Dimana pengakuan aset yang terjadi di grup tunas muda ditinjau dari pihak yang memberikan sumbangan pengakuan aset tersebut diakui pada saat pertama kali mereka memberikan sumbangan kepada orang lain dan manfaat ekonomiknya akan diperoleh pada masa yang akan datang pada saat pengembalian terkait dengan sumbangan yang diberikan sebelumnya, sedangkan bagi pihak yang menerima sumbangan mengakui sumbangan sebagai aset pada saat sumbangan sudah diterima dan manfaat ekonomiknya akan diperoleh pada saat hasil sumbangan tersebut dijual. Sedangkan untuk pengukuran aset dalam praktiknya menyesuaikan dengan nilai harga yang terbaru. Selain itu pencatatan aset dalam pelaksanaan tradisi tompangan sumbangan tersebut dicatat dalam daftar hadir dan kwitansi. Dan untuk pelaporan aset yang terjadi di grup tunas muda melakukan pelaporan dengan memberikan bukti adanya daftar hadir dan kwitansi yang dimiliki antar kedua belah pihak dalam pelaksanaan tradisi tompangan yang terjadi di acara pernikahan.

\section{Keterbatasan}

Keterbatasan dalam pelaksanaan penelitian ini adalah sebagai berikut:

1. Minimnya bahan referensi pada saat melakukan penelitian ini yang menyebabkan penulis memiliki kendala.

2. Minimnya informasi yang diperoleh dari informan yang dijadikan objek penelitian. Hal ini dikarenakan ada beberapa informan yang masih sulit untuk ditemui.

\section{Saran}

Bagi peneliti selanjutnya, dapat dijadikan sebagai bahan referensi tentang tradisi tompangan di daerah lain sehingga dalam penelitian selanjutnya dapat membandingkan terkait dengan tradisi tompangan yang terjadi di grup tunas muda dengan tradisi tompangan di daerah lainnya. Selain itu peneliti selanjutnya diharapkan dapat mengungkap lebih mendalam terkait dengan adanya pengembalian sumbangan yang lebih besar dari sebelumnya yang diakibatkan oleh adanya perubahan nilai mata uang dalam pelaksanaan tradisi tompangan.

\section{REFERENSI}

Damsar, \& Indrayani. (2016). Pengantar Sosiologi Ekonomi. Jakarta: Prenadamedia Group.

Geertz, C. (2014). Agama Jawa: Abangun, Santri, Priyayi dalam Kebudayaan Jawa. Depok: Komunitas Bambu.

Hantono, \& Rahmi, N. U. (2018). Pengantar Akuntansi. Yogyakarta: 
Deepublish.Margahana, H., \& Triyanto, E. (2019). Membangun Tradisi Entrepreneurship Pada Masyarakat. Edunomika, 03(02), 300-309.

Pribadhi, P. A. (2011). Resiprositas Dalam Kehidupan Sosial Ekonomi Masyarakat (Studi Kasus Pada Masyarakat Kelurahan Kauman Kabupaten Blora). Skripsi Universitas Negeri Semarang.

Saputri, E. D., \& Ashari, M. H. (2019). Tradisi Buwuh Dalam Perspektif Akuntansi Piutang dan Hibah di Kecamatan Lowokwaru Kota Malang. PRIVE, 2(1), 16-25.

Sasongko, C., Setyaningrum, A., Febriana, A., Hanum, A. N., Pratiwi, A. D., \& Zaryati, V. (2017). Akuntansi Suatu Pengantar : Berbasis PSAK. Salemba Empat.

Sochib. (2018). Pengantar Akuntansi 1. Yogyakarta: Deepublish.

Sugiyono. (2015). Metode Penelitian Pendidikan : Pendekatan Kuantitatif, Kualitatif dan $R \& D$. Bandung: Alfabeta. 